\title{
Glucose-induced hyperproliferation of cultured rat aortic smooth muscle cells through polyol pathway hyperactivity
}

\author{
J. Nakamura, Y. Kasuya, Y.Hamada, E. Nakashima, K. Naruse, Y. Yasuda, K. Kato, N. Hotta \\ The Third Department of Internal Medicine, Nagoya University School of Medicine, Nagoya Japan
}

\begin{abstract}
Aims/hypothesis. The protein kinase C (PKC), platelet-derived growth factor (PDGF) and polyol pathway play important parts in the hyperproliferation of smooth muscle cells, a characteristic feature of diabetic macroangiopathy. The precise mechanism, however, remains unclear. This study investigated the relation between polyol pathway, protein kinase $\mathrm{C}$ and platelet-derived growth factor in the development of diabetic macroangiopathy.

Methods. Smooth muscle cells were cultured with 5.5 or $20 \mathrm{mmol} / \mathrm{l}$ glucose with or without an aldose reductase inhibitor, epalrestat, or a PKC- $\beta$ specific inhibitor, LY333 531. Protein kinase C activities, the expression of $\mathrm{PKC}-\beta \mathrm{II}$ isoform and PDGF- $\beta$ receptor protein, free cytosolic $\mathrm{NAD}^{+}: \mathrm{NADH}$ ratio, the contents of reduced glutathione, and proliferation activities were measured.

Results. Smooth muscle cells cultured with $20 \mathrm{mmol} / \mathrm{l}$ glucose showed statistically significant increases in protein kinase $\mathrm{C}$ activities, the expression of PKC$\beta \mathrm{II}$ isoform and $\mathrm{PDGF}-\beta$ receptor protein, and prolif-
\end{abstract}

eration activities, compared with smooth muscle cells cultured with $5.5 \mathrm{mmol} / 1$ glucose. Although epalrestat and LY333531 inhibited protein kinase C activation induced by glucose to the same degree, the effects of epalrestat on proliferation activities and expression of the PDGF- $\beta$ receptor were more prominent than those of LY333531. Epalrestat improved the glucose-induced decrease in free cytosolic $\mathrm{NAD}^{+}: \mathrm{NADH}$ ratio and reduced glutathione content, but LY333531 did not. The increased expression of membranous $\mathrm{PKC}-\beta \mathrm{II}$ isoform was normalized by epalrestat.

Conclusion/interpretation. These observations suggest that polyol pathway hyperactivity contributes to the development of diabetic macroangiopathy through protein kinase $\mathrm{C}, \mathrm{PDGF}-\beta$ receptor, and oxidative stress, and that an aldose reductase inhibitor has a therapeutic value for this complication. [Diabetologia (2001) 44: 480-487]

Keywords Aldose reductase inhibitor, protein kinase $\mathrm{C}$, platelet-derived growth factor, diabetic macroangiopathy, oxidative stress.
Diabetes mellitus is one of the major risk factors for atherosclerosis and is associated with an increased in-

Received: 2 October 2000 and in revised form: 13 December 2000

Corresponding author: J. Nakamura, MD, The Third Department of Internal Medicine, Nagoya University School of Medicine, 65 Tsuruma-cho, Showa-ku, Nagoya 466-8550, Japan Abbreviations: ARI, Aldose reductase inhibitor; PDGF, platelet derived growth factor; PKC, protein kinase C; GSH, reduced glutathione. cidence of coronary heart diseases and cerebrovascular diseases $[1,2]$. The high prevalence of these macrovascular diseases in diabetic patients can be explained by hyperglycaemia in itself [3] as well as by the increased frequency of conventional risk factors such as hypertension, hyperlipidemia, obesity, and smoking.

The proliferation of vascular smooth muscle cells is one of the characteristic features of atherosclerosis [4]. According to previous reports [4, 5], platelet-derived growth factor (PDGF) plays an important part in the accelerated proliferation of smooth muscle 
cells, and it has recently been reported that smooth muscle cells from diabetic animals over-react upon PDGF stimulation, which is mediated through the overexpression of the PDGF- $\beta$ receptor [5].

Hyperglycaemia leads to various metabolic abnormalities such as increased polyol pathway activity, altered protein kinase $\mathrm{C}$ (PKC) activities, increased oxidative stress, and enhanced non-enzymatic glycation [6]. In our previous study [7] an aldose reductase inhibitor (ARI) prevented intimal thickening in coronary arteries of galactose-fed beagle dogs, suggesting that polyol pathway hyperactivity plays an important part in the development of diabetic macroangiopathy. We also reported that epalrestat prevented the glucose-induced increase in the proliferation activities and PDGF- $\beta$ receptor expression in cultured smooth muscle cells [8]. On the other hand, it has been reported that increased PKC activities contribute to the development of diabetic macroangiopathy [9] as well as nephropathy [10], retinopathy [11], and neuropathy [12], and that a PKC- $\beta$ specific inhibitor can prevent these complications. In addition, the hyperglycaemia-induced increase in oxidative stress [13-16] is considered to be an important factor in the development of diabetic vascular complications [17]. Reactive oxygen species stimulate smooth muscle cell growth [18], and antioxidants, probucol, and $\alpha$ tocopherol reduce the high glucose-induced proliferation of smooth muscle cells [19]. Furthermore, although previous reports $[20,21]$ have suggested that increases in polyol pathway activity, PKC activities, and oxidative stress are closely related to each other, the precise interrelation between these abnormalities remains controversial.

Therefore, this study investigated the relation between the polyol pathway, PKC, oxidative stress, and PDGF in the pathogenesis of diabetic macroangiopathy by measuring PKC activities, the expression of $\mathrm{PKC}-\beta \mathrm{II}$ isoform and PDGF- $\beta$ receptor protein, free cytosolic $\mathrm{NAD}^{+}: \mathrm{NADH}$ ratio, the contents of reduced glutathione (GSH), and proliferation activities in rat aortic smooth muscle cells cultured with 5.5 or $20 \mathrm{mmol} / \mathrm{l}$ glucose in the presence or absence of a PKC- $\beta$ specific inhibitor, LY333531 (11), or an aldose reductase inhibitor, epalrestat [22].

\section{Methods and research design}

Materials. Reagents were obtained from the following sources: rat aortic smooth muscle cells, A10 cells (ATCC CRL1496), from American Type Culture Collection (Rockville, Md., USA); Dulbecco's modified Eagle medium (DMEM), penicillin-streptomycin, and fetal bovine serum (FBS) from Gibco (Grand Island, N.Y., USA); sodium dodecyl sulfate (SDS) and trichloroacetic acid (TCA) from Sigma (St. Louis, Mo., USA); Whatman GF/C filter and $3 \cdot 3 \mathrm{~cm}$ phosphocellulose papers (P-81) from Whatman International (Maidstone, UK); polyclonal anti-PDGF- $\beta$ receptor antibody from Upstate Bio- technology (Lake Placid, N. Y., USA); antibodies for PKC- $\alpha$ and PKC- $\beta$ II isoform from Santa Cruz Biotechnology (Santa Cruz, Calif., USA), $\left[\gamma^{32} \mathrm{P}\right]$-ATP from New England Nuclear (Boston, Mass., USA); epalrestat (E-3-carboxymethyl-5-(2Emethyl-3-phenylpropemylidene) rhodanine) and LY333531 were kindly provided by Ono Pharmaceutical Co. (Osaka, Japan) and Eli Lilly (Indianapolis, Ind., USA), respectively.

Cell culture. Smooth muscle cells were grown in DMEM containing $5.5 \mathrm{mmol} / 1$ glucose, penicillin $(100 \mathrm{U} / \mathrm{ml})$-streptomycin $(100 \mathrm{mg} / \mathrm{ml})$, and $10 \% \mathrm{FBS}, \mathrm{pH} 7.40$, at $37^{\circ} \mathrm{C}$ in a humidified $5 \% \mathrm{CO}_{2} / 95 \%$ air atmosphere. Third- or fourth-passage cells from the purchase allowed to grow for three weeks in DMEM containing 5.5 or $20 \mathrm{mmol} / \mathrm{l}$ glucose with or without LY333531 $(2-200 \mathrm{nmol} / \mathrm{l})$ or epalrestat $(0.1-10 \mu \mathrm{mol} / \mathrm{l})$ were used in the following experiments. Subculture after tripsinization was done on a weekly basis since the cells became confluent in a week. The medium was replaced with fresh medium every other day.

Assay of PKC activities. Cells were plated on 12-well plates at a density of $8 \cdot 10^{3}$ cells $/ \mathrm{cm}^{2}$ and grown in each experimental medium as described above. The cells were washed twice and preincubated for $1 \mathrm{~h}$ in serum-free DMEM. Protein kinase $\mathrm{C}$ activities in smooth muscle cells were measured as described previously [23] with minor modifications. Briefly, cells were rinsed twice with $2 \mathrm{ml}$ of DMEM containing $20 \mathrm{mmol} / \mathrm{l}$ HEPES ( $\mathrm{pH}$ 7.4) and then with $2 \mathrm{ml}$ of salt solution $(137 \mathrm{mmol} / \mathrm{l} \mathrm{NaCl}$, $5.4 \mathrm{mmol} / \mathrm{l} \mathrm{KCl}, 0.3 \mathrm{mmol} / \mathrm{l}$ sodium phosphate, $0.4 \mathrm{mmol} / \mathrm{l}$ potassium phosphate, $5.5 \mathrm{mmol} / \mathrm{l}$ glucose, $10 \mathrm{mmol} / \mathrm{l} \mathrm{MgCl}_{2}$, $25 \mathrm{mmol} / \mathrm{l}$ ß-glycerophosphate, $5 \mathrm{mmol} / \mathrm{l}$ EGTA, $2.5 \mathrm{mmol} / \mathrm{l}$ $\mathrm{CaCl}_{2}$, and $20 \mathrm{mmol} / \mathrm{l} \mathrm{HEPES}, \mathrm{pH} 7.4$ ). The cells were preincubated with the salt solution for $10 \mathrm{~min}$ at $37^{\circ} \mathrm{C}$ and incubated for another $15 \mathrm{~min}$ in the presence or absence of $100 \mu \mathrm{mol} / \mathrm{l}$ PKC-specific peptide substrate, RKRTLRRL [24] with $50 \mu \mathrm{g}$ / $\mathrm{ml}$ digitonin and $100 \mu \mathrm{mol} / 1\left[\gamma^{3}{ }^{32} \mathrm{P}\right]-\mathrm{ATP}(<1500 \mathrm{cpm} / \mathrm{pmol})$. The reaction was terminated with $5 \%$ TCA (final concentration). Aliquots of the reaction mixture were spotted on $3 \cdot 3 \mathrm{~cm}$ phosphocellulose papers and washed with three changes of $75 \mathrm{mmol} / \mathrm{l}$ phosphoric acid and one change of $75 \mathrm{mmol} / \mathrm{l}$ sodium phosphate $(\mathrm{pH} 7.5)$. The radioactivity of phosphorylated substrate was measured by liquid scintillation counting. Protein contents were measured by the BCA method [25] and PKC activities were expressed in $\mathrm{pmol} / \mathrm{min} / \mathrm{mg}$ protein.

Assay of proliferation activities in smooth muscle cells. The proliferation activities of smooth muscle cells were assessed by the measurement of $\left[{ }^{3} \mathrm{H}\right]$-thymidine incorporation into DNA. Cells were plated on 6-well plates at a density of $10 \cdot 10^{3}$ cells $/ \mathrm{cm}^{2}$ and grown in each experimental medium as described above. After incubation for 5 days, the cells were preincubated with serum-free medium for $48 \mathrm{~h}$, and $37 \mathrm{kBq} /$ well of $\left[{ }^{3} \mathrm{H}\right]$-thymidine was added. At the end of incubation for $1 \mathrm{~h}$, cells were washed with ice-cold phosphate buffered saline (PBS) three times, then dissolved with $0.1 \%$ SDS and extracted with $10 \%$ TCA. The TCA-insoluble fraction was collected on a Whatman $\mathrm{GF} / \mathrm{C}$ filter and the radioactivity was measured with a liquid scintillation counter. The protein contents were measured by the BCA method [25] and the proliferation activities were expressed in $\mathrm{dpm} / \mathrm{mg}$ protein.

Immunoblot analysis of $P K C$ - $\alpha$ and $-\beta I I$ isoform protein. After incubation with each experimental medium, the cells grown on $150 \mathrm{~mm}$-dishes were washed with ice-cold PBS three times, scraped with a scraper, and sonicated. Cells were then lysed in buffer A $(20 \mathrm{mmol} / \mathrm{l}$ Tris- $\mathrm{HCl}, \mathrm{pH} 7.5,0.5 \mathrm{mmol} / 1$ EGTA, $2 \mathrm{mmol} / \mathrm{l}$ EDTA, $1 \mathrm{mmol} / \mathrm{l}$ phenylmethylsulfonyl fluoride, 
$1 \mathrm{mmol} / \mathrm{l}$ dithiothreitol, $0.3 \mathrm{~mol} / \mathrm{l}$ sucrose, $25 \mu \mathrm{g} / \mathrm{ml}$ leupeptin, $100 \mu \mathrm{g} / \mathrm{ml}$ aprotinin) with Polytron for $20 \mathrm{~s}$ and then homogenized with 60 strokes of a Duounce homogenizer. The homogenates were centrifuged at $1000 \cdot \mathrm{g}$ for $10 \mathrm{~min}$ and then the supernatant was ultracentrifuged at $100000 \cdot \mathrm{g}$ for $60 \mathrm{~min}$ at $4{ }^{\circ} \mathrm{C}$. The resulting supernatant was retained as the cytosolic fraction. The pellets were resuspended with buffer B (buffer A without sucrose) and homogenized again. The homogenates were solubilized in buffer B with $1 \%$ Triton X-100 and the soluble fraction was retained as the membranous fraction after ultracentrifugation at $100000 \cdot \mathrm{g}$ for $60 \mathrm{~min}$. Both the membranous and cytosolic fractions were applied to a DEAE column, washed twice with $2 \mathrm{ml}$ buffer B and then finally eluted with $0.4 \mathrm{ml}$ buffer B containing $200 \mathrm{mmol} / \mathrm{l} \mathrm{NaCl}$. After measurement of the protein concentrations, samples containing the same amount of protein $(20-100 \mu \mathrm{g})$ were electrophoresed on SDS-PAGE ( $8 \%$ acrylamide gel) and transferred to a nitrocellulose membrane. The membrane was blocked overnight with ovalbumin and incubated with a PKC- $\alpha$ or PKC- $\beta$ II isoform antibody overnight at $4{ }^{\circ} \mathrm{C}$ followed by incubation with an anti-rabbit polyclonal IgG antibody, and visualized by ECL chemiluminesence detection kits (Amersham Pharmacia Biotech UK, Buckinghamshire, UK). Protein expressions were quantified by densitometry.

Immunoblot analysis of PDGF- $\beta$ receptor protein. After incubation with each experimental medium, the cells grown on $100 \mathrm{~mm}$-dishes were washed with ice-cold PBS three times, scraped, and sonicated. Cells were then lysed in a buffer containing $50 \mathrm{mmol} / \mathrm{l}$ Tris- $\mathrm{HCl}, \mathrm{pH} 7.4,1 \%$ Triton $\mathrm{X}-100,0.25 \%$ sodium deoxycholate, $150 \mathrm{mmol} / \mathrm{l} \mathrm{NaCl}, 1 \mathrm{mmol} / \mathrm{l}$ EGTA, $1 \mathrm{mmol} / 1 \mathrm{PMSF}, 1 \mu \mathrm{g} / \mathrm{ml}$ aprotinin, $1 \mu \mathrm{g} / \mathrm{ml}$ leupeptin, $1 \mu \mathrm{g} / \mathrm{ml}$ pepstatin, $1 \mathrm{mmol} / 1 \mathrm{Na}_{3} \mathrm{VO}_{4}$, and $1 \mathrm{mmol} / \mathrm{l} \mathrm{NaF}$ at $4{ }^{\circ} \mathrm{C}$. After determination of the protein concentrations, samples containing the same amount of protein $(20 \mu \mathrm{g})$ were electrophoresed on SDS-PAGE ( $8 \%$ acrylamide gel) and transferred to a nitrocellulose membrane. The membrane was blocked overnight with ovalbumin and incubated with a polyclonal anti-PDGF- $\beta$ receptor antibody overnight at $4{ }^{\circ} \mathrm{C}$ followed by incubation with an anti-rabbit polyclonal IgG antibody. Receptor ligand complexes were visualized using ECL chemiluminesence detection kits (Amersham Pharmacia Biotech). Protein expressions were quantified by densitometry.

Assay of free cytosolic $N A D^{+}: N A D H$ ratio. The direct measurements of NAD and NADH are not informative in terms of control of metabolism because they do not provide information on compartmentalization of nicotinamide nucleotides between cytosol and mitochondria and they do not separate free from protein-bound forms (only free fractions determine direction and free-energy changes of dehydrogenase reactions). An alternative approach, implying assessment of free $\mathrm{NAD}^{+}$:$\mathrm{NADH}$ ratio in the cytoplasma by measuring the ratio of the concentrations of the oxidized and reduced metabolites of suitable NAD-linked dehydrogenase system has been proposed [26]. Using this approach, free cytosolic $\mathrm{NAD}^{+}: \mathrm{NADH}$ ratio was calculated from metabolite concentrations and the equilibrium constant of lactate dehydrogenase as follows:

$\left[\mathrm{NAD}^{+}\right]:[\mathrm{NADH}]=([$ pyruvate $] /[$ lactate $]) \cdot 1 / \mathrm{k}_{1}$

Where $\mathrm{k}_{1}$ is the equilibrium constant of lactate dehydrogenase $\left(1.1 \cdot 10^{-4} \mathrm{~mol} / \mathrm{l}\right)[27,28]$. Lactate and pyruvate were measured by enzymatic assay $[29,30]$.

Assay of GSH contents. The GSH contents in smooth muscle cells were assayed by the method described previously [31] with minor modifications. After incubation with each experimental medium, the cells grown on $100 \mathrm{~mm}$-dishes were scraped and sonicated. Cells were lysed in cold $10 \%$ TCA and centrifuged at $2700 \mathrm{rpm}$ for $15 \mathrm{~min}$. The supernatant $(100 \mu \mathrm{l})$ was mixed with $0.89 \mathrm{ml}$ of $1.0 \mathrm{~mol} / \mathrm{l}$ Tris $\mathrm{HCl}, \mathrm{pH} 8.2$, containing $0.02 \mathrm{~mol} / \mathrm{l}$ EDTA. To this mixture, $10 \mu \mathrm{l}$ of DTNB (5,5'-dithio-bis 2-nitrobenzoic acid) solution (99 $\mathrm{mg}$ in $25 \mathrm{ml}$ methanol) was added and the colored product was monitored with a spectrophotometer at $412 \mathrm{~nm}$. The GSH concentration was calculated based on the standard curve $(100-500 \mathrm{ng} / \mathrm{ml})$. Protein contents were measured by the BCA method [25] and $\mathrm{GSH}$ contents were expressed in $\mathrm{nmol} / \mathrm{mg}$ protein.

Statistical analysis. Results are presented as means \pm SEM of at least three measurements for a representative experiment. Each experiment was replicated in triplicate. Differences among experimental groups were detected by analysis of variance, and the differences between groups were assessed by Bonferroni/Dunn test. Statistical significance was defined as a $p$ value of less than 0.05 .

\section{Results}

Effects of epalrestat (Figure 1A.) and LY333531 (Figure $1 B$.) on PKC activities in smooth muscle cells cultured with 5.5 or $20 \mathrm{mmol} / \mathrm{l}$ glucose. Protein kinase C activities in smooth muscle cells under the $20 \mathrm{mmol} / \mathrm{l}$ glucose condition (A: $34.9 \pm 2.7, \mathrm{~B}: 35.4 \pm 1.7 \mathrm{pmol} /$ $\mathrm{min} / \mathrm{mg}$ protein, $p<0.05)$ were increased compared with those under the $5.5 \mathrm{mmol} / \mathrm{l}$ glucose condition (A: $21.5 \pm 1.3$, B: $19.0 \pm 1.7$ ). The glucose-induced increase in PKC activities was ameliorated by epalrestat and LY333531 in a dose dependent fashion, and was almost normalized at the concentrations of $10 \mu \mathrm{mol} / \mathrm{l}(22.6 \pm 0.6)$ and $200 \mathrm{nmol} / \mathrm{l}(21.1 \pm 1.6)$, respectively. On the other hand, neither epalrestat nor LY333531 affected the PKC activities under the $5.5 \mathrm{mmol} / \mathrm{l}$ glucose condition. Therefore, these concentrations were used in the following experiments.

Effect of epalrestat on the expression of PKC- $\alpha$ and $P K C$ - $\beta I I$ isoform protein in smooth muscle cells cultured with 5.5 or $20 \mathrm{mmol} / \mathrm{l}$ glucose. Protein kinase C isoform proteins in smooth muscle cells were characterized by using monospecific polyclonal antibodies against $\mathrm{PKC}-\alpha$ or $\mathrm{PKC}-\beta \mathrm{II}$ isoforms. The expression of $\mathrm{PKC}-\beta \mathrm{II}$ isoform protein in the membrane fraction of smooth muscle cells cultured in $20 \mathrm{mmol} / 1$ glucose $(162.1 \pm 13.5 \%, p<0.05)$ was increased compared with that in $5.5 \mathrm{mmol} / \mathrm{l}$ glucose $(100 \%)$. Epalrestat reduced this increase in the expression of PKC- $\beta$ II isoform protein in the membrane fraction $(98.7 \pm 4.1, p<0.05)$ (Fig. 2). In the cytosolic fraction, there were no statistically significant differences between 5.5 and $20 \mathrm{mmol} / \mathrm{l}$ glucose in the expression of PKC- $\beta$ II isoform protein with or without epalrestat. On the other hand, exposure of the smooth muscle cells to $20 \mathrm{mmol} / \mathrm{l}$ glucose did not affect the PKC- $\alpha$ expression in either the membrane $(5.5 \mathrm{mmol} / \mathrm{l} \mathrm{glu}-$ 

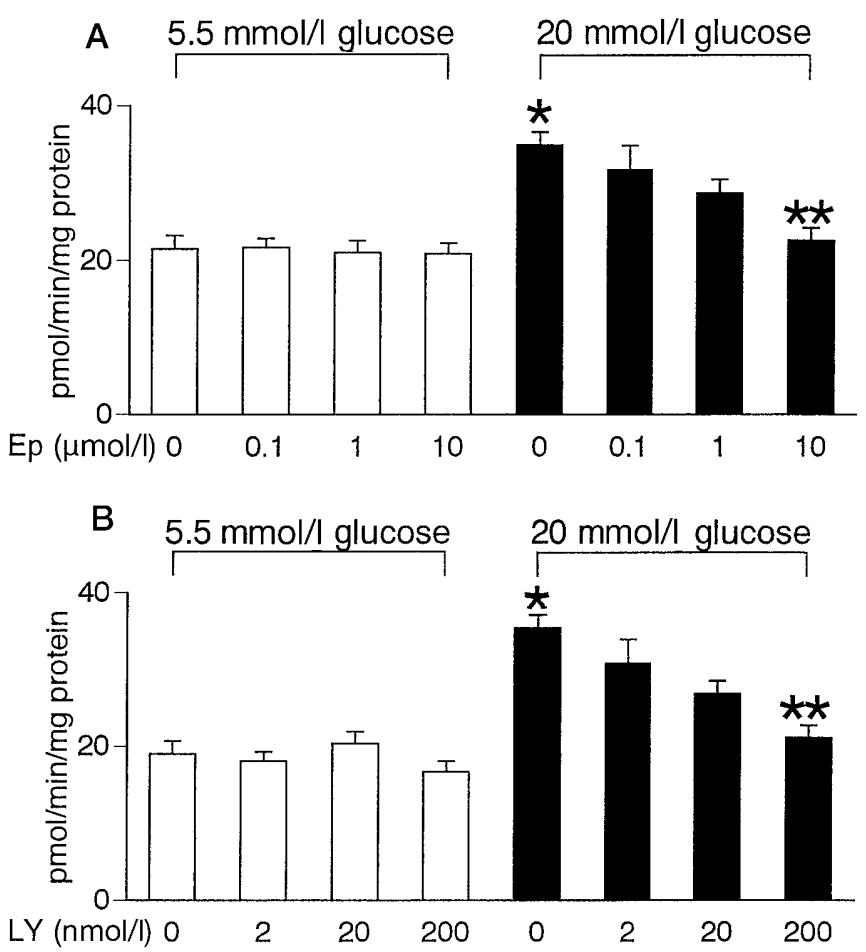

Fig.1A, B. Effect of epalrestat (A) and LY333531 (B) on $\mathrm{PKC}$ activities in smooth muscle cells cultured with $5.5 \mathrm{mmol} / 1$ or $20 \mathrm{mmol} / \mathrm{l}$ glucose. Values are means \pm SEM of 3-6 measurements for a representative experiment. Each experiment was replicated in triplicate. LY: LY333531. Ep: epalrestat. $* p<0.05$ vs $5.5 \mathrm{mmol} / \mathrm{l}$ glucose, $* * p<0.05$ vs $20 \mathrm{mmol} / \mathrm{l}$ glucose

cose: $100 \%, 20 \mathrm{mmol} / \mathrm{l}$ glucose: $107.8 \pm 18.4$ ) or cytosolic fraction $(5.5 \mathrm{mmol} / \mathrm{l}$ glucose: $100,20 \mathrm{mmol} / \mathrm{l} \mathrm{glu}-$ cose: $108.9 \pm 6.0$ ). Epalrestat caused no changes in the PKC- $\alpha$ expression under 5.5 or $20 \mathrm{mmol} / \mathrm{l}$ glucose (data not shown).

Effects of epalrestat and LY333531 on proliferation activities in smooth muscle cells cultured with 5.5 or $20 \mathrm{mmol} / \mathrm{l}$ glucose. The proliferation activities in smooth muscle cells under the $20 \mathrm{mmol} / \mathrm{l}$ glucose condition $\left(2.31 \pm 0.08 \cdot 10^{5} \mathrm{dpm} / \mathrm{mg}\right.$ protein, $\left.p<0.05\right)$ were higher than those in the $5.5 \mathrm{mmol} / \mathrm{l}$ glucose condition $(0.94 \pm 0.01)$. Although epalrestat and LY333531 prevented the $20 \mathrm{mmol} / \mathrm{l}$ glucose-induced acceleration of proliferation activities in smooth muscle cells, this inhibitory effect of epalrestat $(1.20 \pm 0.11, p<0.05)$ was more prominent than that of LY333531 (16.8 \pm 0.06, $p<0.05$ ) (Fig. 3). Neither epalrestat nor LY333531 altered the proliferation activities in smooth muscle cells under the $5.5 \mathrm{mmol} / \mathrm{l}$ glucose condition.

Effects of epalrestat and LY333531 on the expression of PDGF- $\beta$ receptor protein in smooth muscle cells cultured with 5.5 or $20 \mathrm{mmol} / \mathrm{l}$ glucose. The expression of PDGF- $\beta$ receptor protein was increased in smooth muscle cells cultured with $20 \mathrm{mmol} / \mathrm{l}$ glucose membranous PKC-BII

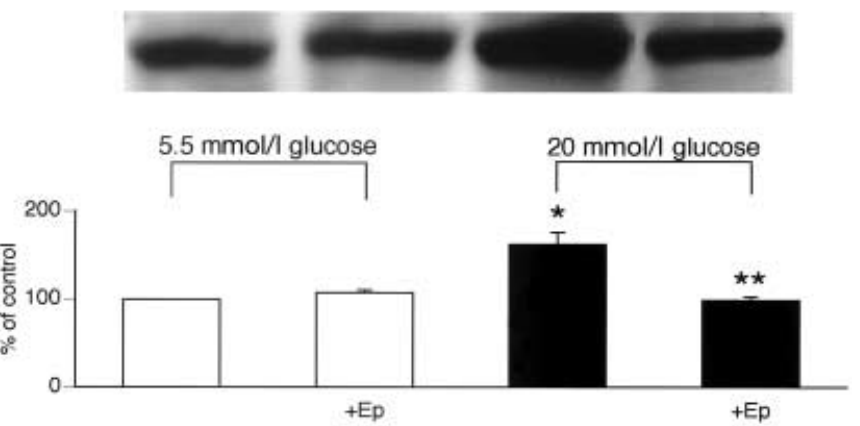

cytosolic PKC-ßII
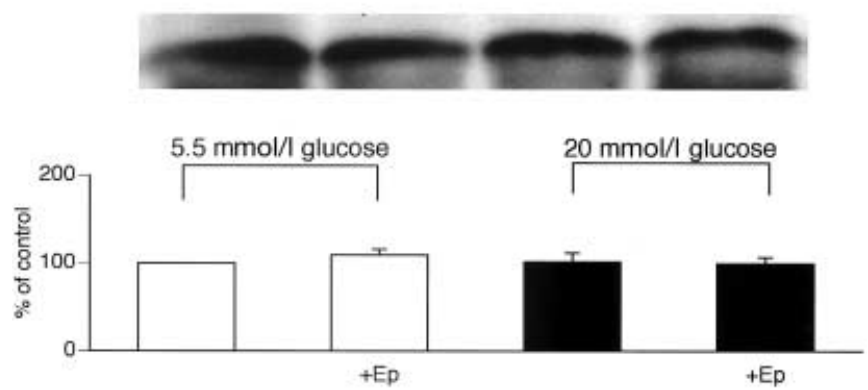

Fig. 2. Effect of epalrestat on the expression of PKC- $\beta$ II protein in smooth muscle cells cultured with $5.5 \mathrm{mmol} / \mathrm{l}$ or $20 \mathrm{mmol} / 1$ glucose. Values are means \pm SEM of 3-6 measurements for a representative experiment. Each experiment was replicated in triplicate. Ep: epalrestat $(10 \mu \mathrm{mol} / \mathrm{l})$. ${ }^{*} p<0.05$ vs $5.5 \mathrm{mmol} / 1$ glucose, $* * p<0.05$ vs $20 \mathrm{mmol} / 1$ glucose

$(184.7 \pm 9.4 \%, p<0.05)$ compared with that cultured with $5.5 \mathrm{mmol} / \mathrm{l}$ glucose (100\%). The LY333531 ameliorated the $20 \mathrm{mmol} / \mathrm{l}$ glucose-induced acceleration of PDGF- $\beta$ receptor expression (144.8 \pm 6.1 , $p<0.05)$. On the other hand, epalrestat normalized the increased PDGF- $\beta$ receptor expression (113.7 \pm $3.5)$, and there were statistically significant differences in the inhibitory effect between epalrestat and LY333531 (Fig. 4). Neither epalrestat nor LY333531 showed statistically significant effects on the expression of PDGF- $\beta$ receptor protein in smooth muscle cells under the $5.5 \mathrm{mmol} / \mathrm{l}$ glucose condition.

Effects of epalrestat and LY333531 on free cytosolic $N A D^{+}: N A D H$ ratio in medium and smooth muscle cells cultured with 5.5 or $20 \mathrm{mmol} / \mathrm{l}$ glucose. Although there were no statistically significant changes in free cytosolic $\mathrm{NAD}^{+}: \mathrm{NADH}$ ratio of the culture medium between each condition, free cytosolic NAD ${ }^{+}: \mathrm{NADH}$ ratio in smooth muscle cells cultured with $20 \mathrm{mmol} / 1$ glucose was lower than that with $5.5 \mathrm{mmol} / \mathrm{l}$ glucose $(p<0.05)$. This $20 \mathrm{mmol} / \mathrm{l}$ glucose-induced decrease in free cytosolic $\mathrm{NAD}^{+}$:NADH ratio in smooth muscle cells was ameliorated by epalrestat but not by LY333531 $(p<0.05)$ (Table 1). 


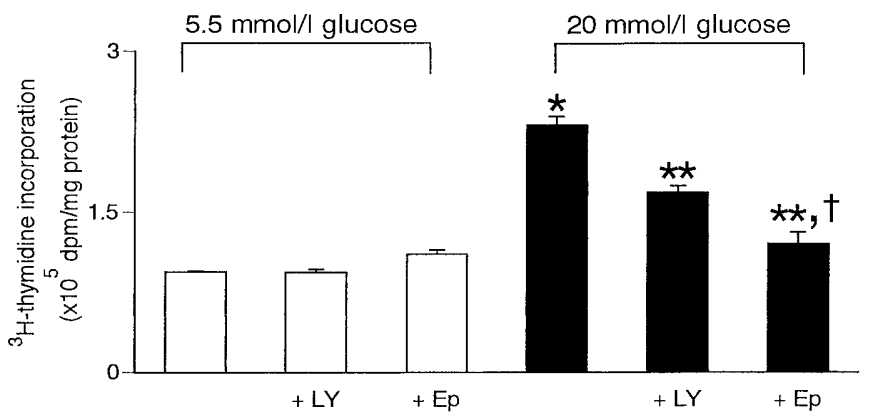

Fig.3. Effects of epalrestat and LY333531 on proliferation activities in smooth muscle cells cultured with 5.5 or $20 \mathrm{mmol} / \mathrm{l}$ glucose. Values are means \pm SEM of 3-6 measurements for a representative experiment. Each experiment was replicated in triplicate. LY: LY333531 (200 nmol/l), Ep: epalrestat $(10 \mu \mathrm{mol} / \mathrm{l})$. $* p<0.05$ vs $5.5 \mathrm{mmol} / 1$ glucose, $* * p<0.05$ vs $20 \mathrm{mmol} / \mathrm{l}$ glucose,${ }^{\dagger} p<0.05 \mathrm{vs} 20 \mathrm{mmol} / \mathrm{l}$ glucose $+\mathrm{LY}$
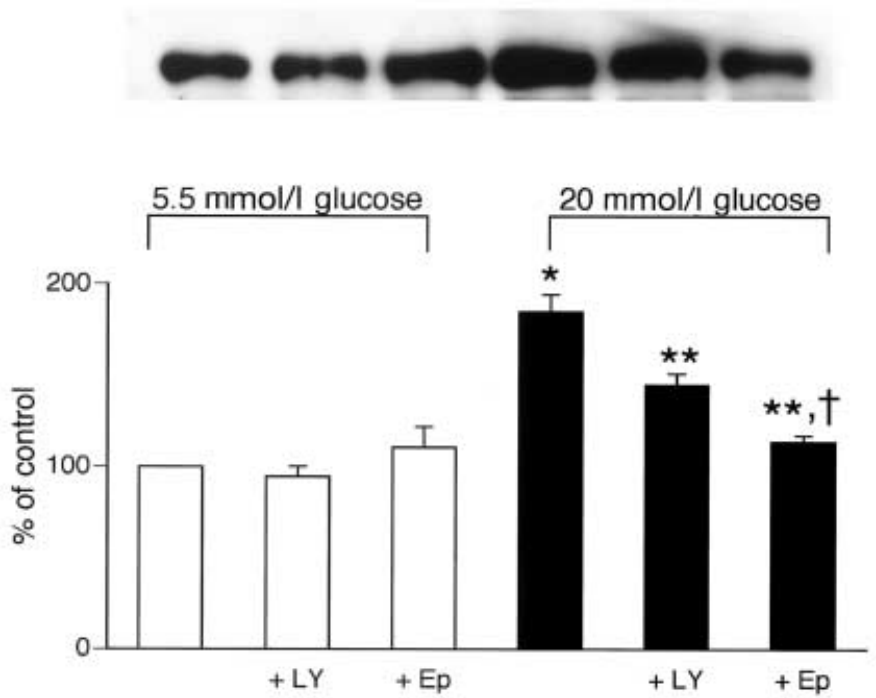

Fig.4. Effect of epalrestat and LY333531 on the expression of PDGF- $\beta$ receptor protein in smooth muscle cells cultured with 5.5 or $20 \mathrm{mmol} / \mathrm{l}$ glucose. Values are means \pm SEM of 3-6 measurements for a representative experiment. Each experiment was replicated in triplicate. LY: LY333531 (200 nmol/l), Ep: epalrestat $(10 \mu \mathrm{mol} / \mathrm{l}) .{ }^{*} p<0.05 \mathrm{vs} 5.5 \mathrm{mmol} / \mathrm{l} \mathrm{glu}-$ cose, ${ }^{* *} p<0.05$ vs $20 \mathrm{mmol} / 1$ glucose,${ }^{\dagger} p<0.05$ vs $20 \mathrm{mmol} / 1$ glucose + LY

Effects of epalrestat and LY333531 on GSH content in smooth muscle cells cultured with 5.5 or $20 \mathrm{mmol} / \mathrm{l}$ glucose. The GSH content in smooth muscle cells cultured with $20 \mathrm{mmol} / \mathrm{l}$ glucose was decreased compared with that cultured with $5.5 \mathrm{mmol} / 1$ glucose $(p<0.05)$. LY333531 had no effect on the $20 \mathrm{mmol} / \mathrm{l}$ glucose-induced decrease in the GSH content, but epalrestat normalized this deficit in GSH content (Table 1). Neither LY333531 nor epalrestat altered the GSH content in smooth muscle cells cultured with $5.5 \mathrm{mmol} / \mathrm{l}$ glucose.
Table 1. Effects of epalrestat and LY333531 on free cytosolic $\mathrm{NAD}^{+}: \mathrm{NADH}$ ratio and GSH content in medium and/or smooth muscle cells cultured with 5.5 or $20 \mathrm{mmol} / \mathrm{l}$ glucose.

\begin{tabular}{|c|c|c|c|}
\hline & \multicolumn{2}{|c|}{$\mathrm{NAD}^{+}: \mathrm{NADH}$} & \multirow{2}{*}{$\begin{array}{l}\mathrm{GSH} \\
(\mathrm{nmol} / \mathrm{mg} \\
\text { protein) }\end{array}$} \\
\hline & medium & $\begin{array}{l}\text { smooth } \\
\text { muscle cells }\end{array}$ & \\
\hline $5.5 \mathrm{mmol} / 1$ glucose & $4978 \pm 112$ & $4160 \pm 454$ & $5.34 \pm 0.32$ \\
\hline $5.5 \mathrm{mmol} / 1$ glucose $+\mathrm{LY}$ & $4978 \pm 67$ & $3900 \pm 474$ & $5.10 \pm 0.55$ \\
\hline $5.5 \mathrm{mmol} / 1$ glucose + Ep & $5139 \pm 214$ & $4169 \pm 284$ & $5.42 \pm 0.74$ \\
\hline $20 \mathrm{mmol} / \mathrm{l}$ glucose & $4664 \pm 78$ & $2217 \pm 180^{\mathrm{a}}$ & $2.04 \pm 0.34^{\mathrm{a}}$ \\
\hline $20 \mathrm{mmol} / 1$ glucose $+\mathrm{LY}$ & $4868 \pm 107$ & $2693 \pm 315$ & $2.48 \pm 0.32$ \\
\hline $20 \mathrm{mmol} / \mathrm{l}$ glucose $+\mathrm{Ep}$ & $4549 \pm 186$ & $4589 \pm 724^{b}$ & $5.24 \pm 0.60^{\mathrm{b}}$ \\
\hline
\end{tabular}

Values are means \pm SEM of 3-6 measurements for a representative experiment. Each experiment was replicated in triplicate. LY: LY333531 (200 nmol/l). Ep: epalrestat $(10 \mu \mathrm{mol} / \mathrm{l})$

${ }^{\mathrm{a}} p<0.05$ vs $5.5 \mathrm{mmol} / \mathrm{l}$ glucose

${ }^{\mathrm{b}} p<0.05$ vs $20 \mathrm{mmol} / \mathrm{l}$ glucose

\section{Discussion}

In this study, rat aortic smooth muscle cells cultured with $20 \mathrm{mmol} / \mathrm{l}$ glucose showed increased proliferation activities, which were accompanied by increases in PKC activities and the expression of PDGF- $\beta$ receptor protein. Although an aldose reductase inhibitor, epalrestat, and a PKC- $\beta$ specific inhibitor, LY333531, inhibited the glucose-induced PKC activation to the same degree, the inhibitory effect of epalrestat on the increases in proliferation activities and the expression of PDGF- $\beta$ receptor was more prominent than that of LY333531. In addition, epalrestat normalized the altered redox state and accelerated oxidative stress.

In this study, the dose dependent effect of epalrestat on the polyol pathway intermediate concentrations was not studied. In our previous studies [8, 32], $100 \mu \mathrm{mol} / \mathrm{l}$ epalrestat completely prevented the glucose-induced sorbitol accumulation and myo-inositol depletion in cultured smooth muscle cells, and $10 \mu \mathrm{mol} / \mathrm{l}$ epalrestat improved these deficits. In addition, epalrestat decreased the glucose-induced hyperproliferation and overexpression of PDGF- $\beta$ receptor protein in a dose dependent fashion, and normalized these abnormalities at the concentration of $10 \mu \mathrm{mol} / \mathrm{l}$. Furthermore, $10 \mu \mathrm{mol} / \mathrm{l}$ epalrestat normalized the glucose-induced PKC activation (Fig.1). Therefore, in this study we used $10 \mu \mathrm{mol} / \mathrm{l}$ epalrestat.

Increases in PKC activities have been reported in tissues of diabetic rats such as kidney, retina, aorta, and heart, or in cells cultured with high ambient glucose such as mesangial cells, smooth muscle cells, and endothelial cells [11, 33-38]. These observations suggest that hyperglycemia-induced PKC activation plays an important part in the development of diabetic complications including micro-angiopathy and macro-angiopathy. Further, among the various isoforms of PKC, the importance of preferential activation of PKC- $\beta$ isoform has been confirmed in vivo by 
the fact that treatment of diabetic rats or PKC- $\beta$ isoform-overexpressing transgenic mice with LY333531 improved the functional and histological abnormalities in kidney and heart $[10,11,39]$. Neither the in vivo effect of LY333531 on atherosclerosis in diabetes nor the in vitro effect on the hyperproliferation of vascular smooth muscle cells cultured with high glucose has been well established. Our finding that the activities of PKC, especially PKC- $\beta$ II isoform, are increased in smooth muscle cells cultured with high glucose are consistent with those of previous studies [35-37]. This increase was accompanied by hyperproliferation activities and the increased expression of PDGF- $\beta$ receptor protein. Furthermore, LY333531 prevented all of these abnormalities. In addition, a recent study reported that the antisence oligonucleotide to PKC- $\beta$ isoform inhibited the high glucose-induced hyperproliferation activities and overexpression of PDGF- $\beta$ receptor [20]. Based on these findings, the hyperproliferation of smooth muscle cells under a high glucose condition is mediated through the $\mathrm{PKC}-\beta$-PDGF- $\beta$ receptor cascade.

The polyol pathway consists of two enzymatic reactions. The first step, glucose to sorbitol, is catalyzed by aldose reductase, and the second step, sorbitol to fructose, by sorbitol dehydrogenase. These reactions include the co-enzyme system and polyol pathway hyperactivity results in an increase in the ratio of $\mathrm{NADP}^{+}$to NADPH and a decrease in that of NAD ${ }^{+}$ to NADH. The latter stimulates the de novo synthesis of diacylglycerol from glycolytic intermediates, resulting in PKC activation. Therefore, polyol pathway hyperactivity could be closely related with increased PKCactivities. Previous studies [40, 41] have reported, however, that an ARI inhibited neither the de novo synthesis of DAG nor PKC activities in vascular cells cultured with high glucose though the sorbitol accumulation was totally prevented, and thereby concluded that polyol pathway hyperactivity did not involve the DAG-PKC pathway. In contrast, it was recently reported that an aldose reductase inhibitor showed antiproliferative and anti-migrative effects on smooth muscle cells cultured with high glucose through the suppression of PKC- $\beta$ activities [20, 42]. Our results are, in part, consistent with their observations, and suggest the importance of the polyol pathway-DAGPKC- $\beta$-PDGF- $\beta$ receptor cascade in the glucose-induced hyperproliferation of smooth muscle cells.

The most innovative observation of the present study is that the inhibitory effect of LY333531 on the hyperproliferation and overexpression of PDGF- $\beta$ receptor was less prominent than that of epalrestat, which completely prevented these deficits, despite the similarity of their effects on PKC activities. This observation suggests that polyol pathway hyperactivity causes the hyperproliferation of smooth muscle cells not only through mechanisms dependent on, but also those independent of the PKC activation.
LY333531 and epalrestat showed different effects on free cytosolic $\mathrm{NAD}^{+}$to $\mathrm{NADH}$ ratio and reduced glutathione (GSH) content. Neither the altered redox state (represented by free cytosolic $\mathrm{NAD}^{+}$:NADH ratio) nor decreased GSH content in smooth muscle cells was affected by LY333531, but epalrestat normalized these changes. As described above, although the altered redox state is located upstream of the PKC activation and related to the polyol pathway hyperactivity, the synthesis of GSH is not directly related to PKC. Therefore, the PKC-independent mechanisms could include deficits in the glutathione cycle.

Recent studies have suggested that oxidative stress increases smooth muscle cell proliferation [43] and anti-oxidants $[19,44,45]$ suppress the high glucoseinduced proliferation of smooth muscle cells. The increase in oxidative stress could be derived from the accelerated formation and reduced scavenging capacity of oxygen free radicals in diabetes. The glutathione redox cycle is one of the major scavenging systems of oxygen free radicals and is regulated by the intracellular contents of GSH and GSSG (oxidized glutathione), glutathione reductase activities, and NADPH concentrations [46, 47]. Aldose reductase requires NADPH as a coenzyme, and the increased polyol pathway activities lead to a depletion in NADPH, thereby competing with glutathione reductase and hampering GSH generation [48]. Therefore, it is reasonable that the polyol pathway hyperactivity would contribute to an increase in oxidative stress and the hyperproliferation of smooth muscle cells through the reduction in GSH, which was confirmed by the fact that epalrestat completely prevented the glucose-induced decrease in the GSH content in this study. In addition, it has been reported that the growth of smooth muscle cells in response to PDGF is dependent on reactive oxygen species [49], and that GSH inhibits the high glucose-induced oxidative damage and the increased PDGF secretion in cultured endothelial cells [50]. Therefore, the polyol pathway-oxidative stress-PDGF cascade independent of PKC could contribute to the glucose-induced hyperproliferation of smooth muscle cells.

Another mechanism of the glucose-induced hyperproliferation of smooth muscle cells may include the accelerated formation of advanced glycation end products (AGE). Advanced glycation end products stimulates the proliferation of smooth muscle cells [51] and the polyol pathway hyperactivity induces an acceleration of AGE formation via 3-deoxyglucosone [52]. We also reported that epalrestat prevented the increase in carlboxymethyllysin, one of the AGE, in aortas of galactosemic dogs [53]. Therefore, the effect of epalrestat observed could be at least in part mediated through the inhibition of AGE formation.

In summary, rat aortic smooth muscle cells cultured with high glucose showed statistically signifi- 
cant increases in PKC activities, the expression of PKC- $\beta$ II isoform and PDGF- $\beta$ receptor protein, oxidative stress, and proliferation activities. Although both epalrestat and LY333531 inhibited PKC activation by high glucose to the same degree, the inhibitory effect of epalrestat on the increases in proliferation activities, the expression of PDGF- $\beta$ receptor, and oxidative stress was more prominent than that of LY333531. In addition, epalrestat improved the high glucose-induced decrease in free cytosolic $\mathrm{NAD}^{+}: \mathrm{NADH}$ ratio and $\mathrm{GSH}$ content, but LY333531 did not. The increased expression of PKC- $\beta$ II isoform was also normalized by epalrestat. These observations suggest that the polyol pathway hyperactivity contributes to the development of diabetic macroangiopathy not only through PKC activation and overexpression of PDGF- $\beta$ receptor but also through increased oxidative stress, and that an aldose reductase inhibitor has therapeutic value for this complication.

Acknowledgements. This work was supported in part by a Diabetes Research grant from the Ministry of Health and Welfare of Japan. The authors thank Ms. Hiromi Kitagawa and Satsuki Uno for their technical assistance.

\section{References}

1. Laakso M, Lehto S (1997) Epidemiology of macrovascular disease in diabetes. Diabetes Rev 5: 294-315

2. Goldschmid MG, Barrett-Connor E, Edelstein SL, Wingard DL, Cohn BA, Herman WH (1994) Dyslipidemia and ischemic heart disease mortality among men and women with diabetes. Circulation 89: 991-997

3. Haller H, Drab M, Luft FC (1996) The role of hyperglycemia and hyperinsulinemia in the pathogenesis of diabetic angiopathy. Clin Nephrol 46: 246-255

4. Ross R (1986) The pathogenesis of atherosclerosis. N Engl Med 314: 488-500

5. Kawano M, Koshikawa T, Kanzaki T, Morisaki N, Saito Y, Yoshida S (1993) Diabetes mellitus induces accelerated growth of aortic smooth muscle cells: association with overexpression of PDGF beta-receptors. Eur J Clin Invest 23: 84-90

6. Greene DA, Sima AA, Stevens MJ, Feldman EL, Lattimer SA. (1992) Complications: neuropathy, pathogenetic considerations. Diabetes Care $15: 1902-1925$

7. Kasuya Y, Ito M, Nakamura J et al. (1999) An aldose reductase inhibitor prevents the intimal thickening in coronary arteries of galactose-fed beagle dogs. Diabetologia 42: 1404-1409

8. Kasuya Y, Nakamura J, Hamada Y et al. (1999) An aldose reductase inhibitor prevents the glucose-induced increase in PDGF-beta receptor in cultured rat aortic smooth muscle cells. Biochem Biophys Res Commun 261: 853-858

9. Koya D, King GL (1998) Protein kinase C activation and the development of diabetic complications. Diabetes 47: 859-866

10. Koya D, Haneda M, Nakagawa H et al. (2000) Amelioration of accelerated diabetic mesangial expansion by treatment with a PKC beta inhibitor in diabetic $\mathrm{db} / \mathrm{db}$ mice, a rodent model for type 2 diabetes. FASEB J 14: 439-447
11. Ishii H, Jirousek MR, Koya D et al. (1996) Amelioration of vascular dysfunctions in diabetic rats by an oral PKC beta inhibitor. Science 272: 728-731

12. Nakamura J, Kato K, Hamada Y et al. (1999) A protein kinase C-beta-selective inhibitor ameliorates neural dysfunction in streptozotocin-induced diabetic rats. Diabetes 48: 2090-2095

13. Williamson JR, Chang K, Frangos M et al. (1993) Hyperglycemic pseudohypoxia and diabetic complications. Diabetes 42: 801-813

14. Sharpe PC, Yue KKM, Catherwood MA, McMaster D, Trimble ER. (1998) The effects of glucose-induced oxidative stress on growth and extracellular matrix gene expression of vascular smooth muscle cells. Diabetologia 41: 1210-1219

15. Sharpe PC, Liu WH, Yue KK et al. (1998) Glucose-induced oxidative stress in vascular contractile cells: comparison of aortic smooth muscle cells and retinal pericytes. Diabetes 47: 801-809

16. Kashiwagi A, Asahina T, Ikebuchi M et al. (1994) Abnormal glutathione metabolism and increased cytotoxicity caused by $\mathrm{H} 2 \mathrm{O} 2$ in human umbilical vein endothelial cells cultured in high glucose medium. Diabetologia 37: 264-269

17. Baynes JW (1991) Role of oxidative stress in development of complications in diabetes. Diabetes 40: 405-412

18. Rao GN, Berk BC (1992) Active oxygen species stimulate vascular smooth muscle cell growth and proto-oncogene expression. Circ Res 70: 593-599

19. Yasunari K, Kohno M, Kano H, Yokokawa K, Minami M, Yoshikawa J (1999) Antioxidants improve impaired insulin-mediated glucose uptake and prevent migration and proliferation of cultured rabbit coronary smooth muscle cells induced by high glucose. Circulation 99: 1370-1378

20. Yasunari K, Kohno M, Kano H, Minami M, Yoshikawa J (2000) Aldose reductase inhibitor improves insulin-mediated glucose uptake and prevents migration of human coronary arter smooth muscle cells induced by high glucose. Hypertension 35: 1092-1098

21. Vinson JA, Staretz ME, Bose P, Kassm HM, Basalyga BS (1989) In vitro and in vivo reduction of erythrocyte sorbitol by ascorbic acid. Diabetes 38: 1036-1041

22. Terashima H, Hama K, Yamamoto R et al. (1984) Effects of a new aldose reductase inhibitor on various tissues in vitro. J Pharmacol Exp Ther 229: 226-230

23. Heasley LE, Johnson GL (1989) Regulation of protein kinase $\mathrm{C}$ by nerve growth factor, epidermal growth factor, and phorbol esters in PC12 pheochromocytoma cells. J Biol Chem 264: 8646-8652

24. Yasuda I, Kishimoto A, Tanaka S, Tominaga M, Sakurai A, Nishizuka Y (1990) A synthetic peptide substrate for selective assay of protein kinase C. Biochem Biophys Res Commun 166: 1220-1227

25. Smith PK, Krohn RI, Hermanson GT et al. (1985) Measurement of protein using bicinchoninic acid. Anal Biochem 150: 76-85

26. Obrosova IG, Fathallah L, Lang HJ, Greene DA (1999) Evaluation of a sorbitol dehydrogenase inhibitor on diabetic peripheral nerve metabolism: a prevention study. Diabetologia 42: 1187-1194

27. Williamson DH, Lund P, Krebs HA (1967) The redox state of free nicotinamide-adenine dinucleotide in the cytoplasm and mitochondria of rat liver. Biochem J 103: 514-527

28. Masuda T, Dobson GP, Veech RL (1990) The Gibbs-Donnan near-equilibrium system of heart. J Biol Chem 265: 20321-20334

29. Gutmann I, WahlefeLd AW (1974) L-( + )-Lactate determination with lactate dehydrogenase and NAD. In: Berg- 
meyer HU (ed) Methods of enzymatic analysis. Vol 3. Academic Press, New York, London, pp 1464-1468

30. Czok R, Lamprecht WB (1974) Pyruvate, phosphoenolpyruvate and D-glycerate-2-phosphate. In: Bergmeyer HU (ed) Methods of enzymatic analysis. Vol 3. Academic Press, New York, London, pp 1446-1451

31. Lou MF, Dickerson JE Jr, Garadi R, York BM Jr (1988) Glutathione depletion in the lens of galactosemic and diabetic rats. Exp Eye Res 46: 517-530

32. Sakakibara F, Hotta N, Koh N, Sakamoto N (1993) Effects of high glucose concentrations and epalrestat on sorbitol and myo-inositol metabolism in cultured rabbit aortic smooth muscle cells. Diabetes 42: 1594-1600

33. Williams B, Howard RL (1994) Glucose-induced changes in $\mathrm{Na}+/ \mathrm{H}+$ antiport activity and gene expression in cultured vascular smooth muscle cells. Role of protein kinase C. J Clin Invest 93: 2623-2631

34. Williams B, Schrier RW (1992) Characterization of glucose-induced in situ protein kinase $\mathrm{C}$ activity in cultured vascular smooth muscle cells. Diabetes 41: 1464-1472

35. Inoguchi T, Xia P, Kunisaki M, Higashi S, Feener EP, King GL (1994) Insulin's effect on protein kinase C and diacylglycerol induced by diabetes and glucose in vascular tissues. Am J Physiol 267: E369-E379

36. Kunisaki M, Bursell SE, Umeda F, Nawata H, King GL (1994) Normalization of diacylglycerol-protein kinase C activation by vitamin $\mathrm{E}$ in aorta of diabetic rats and cultured rat smooth muscle cells exposed to elevated glucose levels. Diabetes 43: 1372-1377

37. Inoguchi T, Battan R, Handler E, Sportsman JR, Heath W, King GL (1992) Preferential elevation of protein kinase C isoform beta II and diacylglycerol levels in the aorta and heart of diabetic rats: differential reversibility to glycemic control by islet cell transplantation. Proc Natl Acad Sci USA 89: 11059-11063

38. Koya D, Jirousek MR, Lin YW, Ishii H, Kuboki K, King GL (1997) Characterization of protein kinase C beta isoform activation on the gene expression of transforming growth factor-beta, extracellular matrix components, and prostanoids in the glomeruli of diabetic rats. J Clin Invest 100: $115-126$

39. Wakasaki H, Koya D, Schoen FJ et al. (1997) Targeted overexpression of protein kinase $C B 2$ isoform in myocardium causes cardiomyopathy. Proc Natl Acad Sci USA 94: 9320-9325

40. Xia P, Inoguchi T, Kern TS, Engerman RL, Oates PJ, King GL (1994) Characterization of the mechanism for the chronic activation of diacylglycerol-protein kinase $\mathrm{C}$ pathway in diabetes and hypergalactosemia. Diabetes 43: 1122-1129

41. Lee TS, MacGregor LC, Fluharty SJ, King GL (1989) Differential regulation of protein kinase $\mathrm{C}$ and $(\mathrm{Na}, \mathrm{K})$-ade- nosine triphosphatase activities by elevated glucose levels in retinal capillary endothelial cells. J Clin Invest 83: 90-94

42. Yasunari K, Kohno M, Kano H, Yokokawa K, Horio T, Yoshikawa J (1995) Aldose reductase inhibitor prevents hyperproliferation and hypertrophy of cultured rat vascular smooth muscle cells induced by high glucose. Arterioscler Thromb Vasc Biol 15: 2207-2212

43. Griendling KK, Ushio-Fukai M (1998) Redox control of vascular smooth muscle proliferation. J Lab Clin Med 132: 9-15

44. Yasunari K, Kohno M, Kano H, Yokokawa K, Minami M, Yoshikawa J (1997) Mechanisms of action of troglitazone in the prevention of high glucose-induced migration and proliferation of cultured coronary smooth muscle cells. Circ Res 81: 953-962

45. Graier WF, Grubenthal I, Dittrich P, Wascher TC, Kostner GM (1995) Intracellular mechanism of high D-glucose-induced modulation of vascular cell proliferation. Eur J Pharmacol 294: 221-229

46. Harlan JM, Levine JD, Callahan KS, Schwartz BR, Harker LA (1995) Glutathione redox cycle protects cultured endothelial cells against lysis by extracellularly generated hydrogen peroxide. J Clin Invest 73: 706-713

47. Schraufstatter IU, Hinshaw DB, Hyslop PA, Spragg RG, Cochrane CG (1985) Glutathione cycle activity and pyridine nucleotide levels in oxidant-induced injury of cells. J Clin Invest 76: 1131-1139

48. Tesfamariam B (1994) Free Radicals in diabetes endothelial cell dysfunction. Free Radic Biol Med 16: 383-391

49. Sundaresan M, Yu ZX, Ferrans VJ, Irani K, Finkel T (1995) Requirement for generation of $\mathrm{H} 2 \mathrm{O} 2$ for plateletderived growth factor signal transduction. Science 270: 296-299

50. Curcio F, Pegoraro I, Dello Russo P, Falleti E, Perrella G, Ceriello A (1995) Sod and GSH inhibit the high glucose-induced oxidative damage and the PDGF increased secretion in cultured human endothelial cells. Thromb Haemost 74: 969-973

51. Satoh H, Togo M, Hara M et al. (1997) Advanced glycation endproducts stimulate mitogen-activated protein kinase and proliferation in rabbit vascular smooth muscle cells. Biochem Biophys Res Commun 239: 111-115

52. Lal S, Randall WC, Taylor AH et al. (1997) Fructose-3phosphate production and polyol pathway metabolism in diabetic rat hearts. Metabolism 46: 1333-1338

53. Hamada Y, Nakamura J, Naruse K, et al. (2000) Epalrestat, an aldose reductase inhibitor, reduces the level of $\mathrm{N}^{\varepsilon}$-(carboxymethyl) lysine protein adducts and their precursors in erythrocytes from diabetic patients. Diabetes Care 23: 1539-1544 